\title{
S5ynthesis
}

International Scientific Conference of IT and Business-Related Research

\section{ETIČKO PONAŠANJE ADOLESCENATA NA INTERNETU}

\section{ETHICAL BEHAVIOUR OF ADOLESCENTS ON THE INTERNET}

\author{
Ivan Nikčević ${ }^{\text {, Elena Marković }}{ }^{2}$ \\ ${ }^{1}$ Univerzitet Singidunum, Poslovni fakultet u Beogradu, Danijelova 32, Beograd, Srbija \\ ${ }^{2}$ Dom učenika srednjih škola Zaječar, Skopljanska bb, Zaječar, Srbija
}

\begin{abstract}
Apstrakt:
Razvoj novih tehnologija, a naročito razvoj informacionih tehnologija, pokreće niz pitanja koja se tiču etike i ističe značaj kompjuterske etike. U radu su prikazani rezultati istraživanja koji se odnose na kompjutersku etiku gde je ispitivano koliko su adolescenti spremni i sposobni da poštuju potrebne standarde zarad očuvanja moralno prihvatljivog ponašanja na internetu, kao i u svakodnevnom životu. Takođe, jedan od ciljeva rada jeste da ispita koliko su adolescenti spremni da se pridržavaju etičkih vrednosti u cilju očuvanja temeljnih vrednosti morala, privatnosti i vlasništva, kao i da analizira socijalni stav učenika prema internetu. Rezultati istraživanja ukazuju na postojanje razlika kod učenika različitog pola kao i na razlike između učenika koji dolaze iz različitih škola, tj. profila za koji se obrazuju.
\end{abstract}

\section{Ključne reči:}

etika, kompjuterska etika, moralno vaspitanje, internet.

\section{UVOD}

„Ne čini drugome ono što ne želiš da drugi čine tebi“

Kant

Savremeni pogledi na smisao čovekovog života podrazumevaju permanentno učenje i usavršavanje, usklađivanje sa mnogim životnim dilemama, izgrađivanje ličnih stavova, postavljanje ciljeva, ostvarivanje ambicija koje su deo svakog pojedinca. Nesumnjivo je da se sve u životu dešava i funkcioniše po nekim pravilima ili normama, pisanim ili nepisanim koje svaka osoba ispunjava ili ne ispunjava.

Društvo stvara norme radi uređenja zajednice i njenog napretka. One mogu biti tehničke prirode i odnose se na postrojenja, a ne na ljude, tiču se prirodnih zakona i ne predviđaju klasičnu sankciju, već predviđaju posledice postupanja ili nepostupanja. Zatim običajne norme gde je pitanje pristojnosti, a ne dobra, odnose se na običaje koji su karakteristični za društvo ili zajednicu i mogu biti privremene. Pravne norme, koje spadaju u red pisanih normi, propisuje država i predviđa određene sankcije za njihovo nepoštovanje. Za navedene norme nije bitno da li se izvršavaju slobodnom voljom ili pod prisilom, već je bitno da se izvršavaju, dok za moralne norme važi pravilo da vrede jedino ako se voljno prihvate i usvoje. Tiču se osobe i bave se dobrom i zlom. Sankcije za nepoštovanje moralnih normi nisu pisane, već osoba samu sebe kažnjava grižom savesti i sl. Važno

\section{Abstract:}

The development of new technologies, in particular information technologies, raises a series of questions related to the issue of ethics and highlights the importance of computer ethics. The paper presents research results that refer to computer ethics, and examines the willingness and the ability of adolescents to comply with the required standards in terms of preserving morally justifiable behaviour on the Internet, and in everyday life. It also aims to determine whether and to what extent the students are ready to comply with the ethical values in order to preserve the fundamental values of ethics, privacy and ownership, and to analyze the students' social attitudes towards the Internet. Research results indicate the existence of differences in students of different sex, as well as among the students coming from different schools, i.e. profile of the learner.

\section{Key words:}

ethics, computer ethics, moral education, Internet.

je napomenuti da pravne norme trebalo da budu usklađene sa moralnim normama ne bi li se postigla njihova potpunija primena, što predstavlja permanentan proces (Singer, 2004).

Nauka koja se bavi moralom i moralnim normama je etika. Reči etika i moral se često poistovećuju, odnosno upotrebljavaju kao sinonimi, ali dolaze iz različitih jezika. Sokrat se smatra osnivačem etike. Na grčkom etika znači običaj, karakter, navika, ćud, što je Ciceron preveo na latinski kao mos, moralis - ono što je ispravno, običaj, vladanje (Singer, 2004). Etika je fundamentalna filozofska disciplina čiji je predmet izučavanja ono što je dobro, što se razlikuje od lepog i bavi se onim što bi trebalo biti a ne onim što jeste. Problematikom morala bave se i druge naučne discipline poput sociologije, koja se bavi istorijom morala u društvenom kontekstu, i psihologije koja istražuje psihološku osnovu morala.

\section{KOMPJUTERSKA ETIKA}

Moderne promene izazvane snažnim razvojem kompjuterske tehnologije i često odsustvo postojećih kriterijuma vrednovanja doprinose sve većem značaju razvoja nove grane primenjene etike, kompjuterske etike. Pojava interneta krajem $\mathrm{XX}$ veka utiče na stvaranje novih odnosa i ukidanje gotovo svih vrsta barijera: granica, jezika, veroispovesti, itd. Ono o čemu smo nekad samo maštali sada, u svom virtuelnom svetu, sada možemo i da doživimo. 
Kompjuterska i informaciona tehnologija, kao i mnoge druge tehnologije pokreću neka moralna pitanja. Kada se kaže druge tehnologije tu se misli na nuklearnu tehnologiju, na globalno zagrevanje i slično. Nove tehnologije donose nove mogućnosti, ali i nove probleme etičke prirode (Džonson, 2006). Džonsonova u svom delu ističe da kompjuterska i informaciona tehnologija, pored koristi koje nam donosi, stvara nove probleme i vakum u propisima. Svakim svojim napredovanjem i usavršavanjem stvara se novi vakum. Postavlja se pitanje ispravnosti mnogih postupaka, kao što je pronalaženje podataka na internetu o nekoj osobi ili preuzimanje odgovornosti za postavljene podatke, kao i njihova tačnost ili netačnost. Danas, na internetu, možete izmeniti i rekonstruisati nečije umetničko ili naučno delo i učiniti razne postupke koji stvaraju vakum u propisima i pokreću niz etičkih pitanja. Menjanjem načina na koji izvršavamo svoje obaveze ili postupke dovodimo u pitanje moralni značaj tog delovanja. „Fizički događaji prilikom nečijeg postupanja u kompjuterizovanom okruženju razlikuju se od onih do kojih dolazi prilikom izvođenja istih tih pokreta u sredini bez kompjutera. Kada pišem olovkom po papiru, olovka se zajedno s rukom pomera po njemu. Dok kucam na mašini, pomeraju se poluge i zupčanici. Dok kucam na kompjuteru, elektronski impulsi menjaju konfiguraciju mikročipova. Dok pišem ovaj primer, promene koje nastaju u fizičkom svetu deluju moralno beznačajno. U sva tri slučaja stvaram reči i tekst" (Džonson, 2006). Kao primer negativnog korišćenja interneta i računara može se navesti i ubacivanje kompjuterskih virusa. „Dobar primer za to bio bi čin ubacivanja kompjuterskog virusa. Kompjuterska tehnologija i internet omogućili su pojedincima da, sedeći u svojoj sobi, pomeraju prste po tastaturi, pritiskaju dugmiće i tim jednostavnim pokretima šalju kompjuterski virus koji je potom u stanju da naudi hiljadama“" (Džonson, 2006). Džonsonova kaže da nije tehnologije ne bi bilo ni te mogućnosti. Postavlja se pitanje da li bi takav postupak imao toliki značaj kada bi bio izveden u fizičkom svetu, drugim vrstama delovanja i da li bi ta osoba takav postupak načinila.

Ključna pitanja koja pokreće kompjuterska etika mogla bi se podeliti na:

- filozofska etika,

- profesionalna etika,

- etika i internet - onlajn etika,

- privatnost,

- vlasništvo,

- odgovornost i kompjuterska tehnologija,

- etika i internet - socijalne implikacije (Džonson, 2006).

Navedena pitanja samo su deo primenjene etike, pa i kompjuterske etike koja bi se mogla analizirati i izučavati.

Postavlja se pitanje kako navedene mogućnosti mogu izazvati niz dilema kod odraslih, zrelih ljudi vezano za ispravnost nečega ili nekog postupka. Kod mladih ljudi, u adolescentnom dobu, to je mnogo lakše. Faze sazrevanja kroz koje prolaze i poremećaji koji se javljaju kao specifičnost adolescencije su kriza identiteta, kriza polnog identiteta (kriza seksualiteta), radna ili akademska inhibicija i kriza autoriteta (normativna kriza). Bez pune podrške stručnih i odraslih osoba nije lako prevazići krize kroz koje prolaze. Nove mogućnosti koje pruža informaciona tehnologija daju drugu dimenziju pomenutim problemima. Naime, mladi putem Interneta pokušavaju da na sebi svojstven način ublaže problem, pritom kršeći određene moralne norme. Lakše ostvaruju kontakt sa drugim osobama, formiraju svoj identitet na internetu onako kako žele, na lakši način obavljaju svoje radne obaveze i slično (Tadić, 2010).

\section{VASPITANJE I MORALNO VASPITANJE}

Osnovni cilj vaspitanja je razvoj ličnosti. Kroz istoriju, on je bio uvek društveno uslovljen. „Cilj vaspitanja predstavlja manje ili više idealno zamišljen ili generalizovan lik čoveka, ličnost određenih svojstava i sposobnosti, koje se žele i nastoje formirati vaspitanjem kod svakog člana određenog društva" (Trnavac \& Đorđević, 2002). Konkretizacija cilja vaspitanja - stvaranje sistema zadataka koje kod čoveka treba razvijati. Po Trnavcu to su: fizičko i zdravstveno vaspitanje, umno i radno vaspitanje, moralno i društveno vaspitanje i estetsko vaspitanje. Razvojem sve četiri strane ličnosti detaljno su određeni zadaci vaspitnog delovanja za svaku oblast. Krneta, Potkonjak i Potkonjak razlikuju: fizičko i zdravstveno vaspitanje, umno vaspitanje, estetsko vaspitanje i moralno vaspitanje (Krneta et al., 1965). Šimleša i saradnici područje vaspitanja dele na sledeće oblasti: fizičko, intelektualno, moralno, estetsko, radno i tehničko vaspitanje (Šimleša et al., 1971). Jednu od novijih podela razvojnih područja daje profesor Suzić, koji je mišljenja da je nastavni plan i program predviđen za obrazovanje određenih profila izuzetno teško primeniti nakon 20 godina kada nauka i tehnologija napreduju velikom brzinom. On pokušava da predvidi potrebe koje će pojedinac imati, kada nastupi radni vek i shodno tome daje dvadeset osam kompetencija za XXI vek. Kompetencije je podelio u četiri područja: kognitivne kompetencije, socijalne kompetencije, emocionalne i radno - tehničke. Po njemu sve ove kompetencije imaju moralnu i estetsku dimenziju (Suzić, 2005).

Moralno vaspitanje predstavlja posebnu komponentu procesa vaspitanja i složen pedagoški proces gde se pojedinac moralno formira i oblikuje u društvenu ličnost. To je proces u okviru kojeg se formiraju njegova moralna svest, moralna osećanja, volja i karakter, navike moralnog ponašanja i delovanja i moralne karakteristike ličnosti. Prvu fazu procesa moralnog formiranja ličnosti čini sticanje moralnih saznanja gde se usvajaju osnovni moralni pojmovi, norme i moralna pravila, upoznaje se sa osnovnim moralnim vrednostima. Druga faza je faza formiranja moralnih uverenja i predstavlja viši stepen u moralnom formiranju ličnosti. Moralna znanja i pojmovi se utemeljuju u ličnost i stvara se određen odnos prema njima. Ličnost počinje da prihvata moralna znanja, kao sopstvene stavove, i ona za njega predstavljaju osnov moralnog ponašanja i delovanja. Jasno je da se moralna uverenja mogu utemeljiti jedino kod osobe koja veruje u njih. Poslednju i najvišu fazu procesa predstavlja formiranje moralnog ponašanja i delovanja. U stvarnom životu, osoba počinje da deluje u skladu sa usvojenim načelima moralnog vaspitanja, poseduje karakteristike volje i karakterne osobe, upornost, umerenost, samostalnost. Faktori koji utiču na usvajanje moralnih normi su neosporno, na prvom mestu porodica, zatim škola, razne institucuje, organizacije, kao i masovni mediji i intenet koji zasigurno ima vodeću ulogu u medijima kod mladih (Popović, 1977).

Kolberg u svom članku iznosi pretpostavku da pomenuti najviši stadijum zavisi od sledećih faktora: pojave neslaganja i izazivanje moralnog sukoba u problematičnim situacijama, i pojave višeg stadijuma mišljenja od onog u kojem se pojedinac nalazi. Uloga nastavnika je da pomaže vaspitaniku da razmatra probleme i načine na koje se može rešavati moralni sukob, da ponovo razmisli o svojim nedostacima u sopstvenom mišljenju i na taj način pređe na viši nivo razmišljanja, tj. nezavisno moralno rasuđivanje (Kohlberg, 1966).

Suzić postavlja pitanje: kako čovek može da se oseća slobodnim kada je njegova sloboda uslovljena voljom drugih? Kao odgovor na pitanje daje Hokingovo mišljenje: „Postoji jedan darvinovski razlog zbog koga verujemo u slobodnu volju: druš- 
tvo u kojem se jedinka oseća odgovornom za svoje postupke ima više izgleda da timski dejstvuje i da preživi, kako bi raširila svoje vrednosti“ (Suzić, 2005). Ovim ističe značaj svojih kompetencija u jačanju samopouzdanja i značaju timskog delovanja.

\section{ISTRAŽIVANJE}

\subsection{PROBLEMATIKA ISTRAŽIVANJA}

Budući da su nam danas kompjuteri i internet sve dostupniji, dolazi do stvaranja novih vrsta moralnih problema i dilema u vezi sa načinom njihovog korišćenja. Mladima je omogućen pristup različitim sadržajima i komunikacija sa drugim korisnicima širom sveta. Internet je postao nezaobilazno sredstvo u nastavi, ali i način korišćenja slobodnog vremena adolescenata. Postavlja se pitanje: da li su mladi upoznati sa opštim moralnim principima i da li ih poštuju prilikom korišćenja novih tehnologija i u kojoj meri?

Istraživanje koje su sproveli Bruski i saradnici (Univerzitet u Torinu, Italija), na uzorku adolescenata prosečne starosti od oko 16,2 godina pokazalo je da mladi često koriste Internet, u svim prilikama, i da su generalno savesni korisnici tehnologije (Bruschi et al., 2009). Iako se čini da su mladi savesni korisnici tehnologije, Bruski i saradnici tvrde da je ipak rano govoriti o istinskoj tehnološkoj kulturi među mladima. Oni koji intenzivno koriste ovu tehnologiju više veruju internetu, pogotovu kada je reč o istinitosti i verodostojnosti informacija na internetu.

Burkart i Švarc su u svom istraživanju o načinu korišćenja interneta došli do zaključka da postoji duboka zabrinutost korisnika interneta u pogledu gubitka kontrole u oblastima koje su vezane za autonomiju, prezentovanje sebe i sopstvene vidljivosti na internetu (Burkart \& Schwarz, 2013). Kada je povećana svest o važnosti digitalne privatnosti kao socijalne i pravne norme u informatičkom društvu, stav prema nadgledanju u vremenu je lagodan.

Istraživanje koje se bavi kršenjem pravnih normi na internetu sprovela je Moli Lend 2013. godine. Ona ističe značaj usvajanja pravnih normi čijim bi se nepoštovanjem sankcionisala zloupotreba na internetu (Land, 2013). Zakon teži da uvek ide u korak sa tehnologijom.

Nikčević i Marković su u svom istraživanju sprovedenom 2013. godine došli do zaključaka da mladi ne koriste internet $\mathrm{u}$ edukativne svrhe u onoj meri koliko im je to dostupno. Većinu vremena na internetu mladi provode slušajući muziku, komunicirajući sa drugovima ili posećujući razne druge sajtove zabavnog karaktera (Nikčević \& Marković, 2013).

Predmet našeg istraživanja je poštovanje etičkih normi na internetu.

\subsection{HIPOTEZE}

U skladu sa postavljenim predmetom i ciljem istraživanja glavna hipoteza je da postoje razlike u pogledu etike, privatnosti, vlasništva i socijalnog stava kao ključnih pitanja kompjuterske etike u odnosu na pol učenika, uspehe i škole koju pohađaju. Iz glavne hipoteze proizilaze posebne hipoteze koje glase:

- Postoje razlike između dečaka i devojčica u pogledu etike, privatnosti, vlasništva i socijalnog stava kao ključnih pitanja kompjuterske etike.

- Postoje razlike između učenika sa različitim uspehom u pogledu etike, privatnosti, vlasništva i socijalnog stava kao ključnih pitanja kompjuterske etike.

- Postoje razlike između učenika različitih škola u pogledu etike, privatnosti, vlasništva i socijalnog stava kao ključnih pitanja kompjuterske etike.

\subsection{METODE I TEHNIKE ISTRAŽIVANJA}

U skladu sa prirodom problema, predmetom, ciljem i zadacima istraživanja, kao i u skladu sa postavljenim hipotezama odabrali smo deskriptivnu metodu istraživanja. Pomoću T - testa i analize varijanse vršeno je poređenje aritmetičkih sredina između različitih grupa ispitanika.

Instrument kojim je sprovedeno istraživanje konstruisan je za potrebe datog istraživanja i test je dat u vidu skale Likertovog tipa na četiri nivoa, preko koje su ispitanici iznosili svoje stavove, odnosno stepen slaganja ili neslaganja sa predloženom tvrdnjom. Nezavisne varijable su pol učenika, uspeh i škola koju pohađaju. Test se sastoji od 17 stavki kojima se potkrepljuju konstrukti koje smo ispitivali.

Pouzdanost skale je utvrđena na osnovu Kronbah-alfa testa (Cronbach's Alpha test). Pouzdanost subskale Vlasništvo je niska $(\alpha=0,31)$ što se može protumačiti malim brojem stavki koje čine ovu subskalu. Pouzdanost subskale Etika je $\alpha=0,68$, subskale Privatnost $\alpha=0,60$ i subskale Socijalni stav $\alpha=0.55$ je nešto ispod donje granice. Međutim, test može biti korišćen i ukoliko su subskale sa koeficijentom ispod donje granice, i ukoliko je unutrašnja konzistentnost visoka (Cortina, 1993). Unutrašnja konzistetnost skale iznosi $\alpha=0,71$, čime je potvrđena pouzdanost čitavog testa.

\subsection{UZORAK}

Uzorkom je obuhvaćeno 340 učenika, stanara domova učenika srednjih škola u Beogradu. S obzirom na veličinu uzorka moguće je donositi izvesne zaključke i predvideti nova istraživanja u okviru populacije koja je ispitivana.

Opis uzorka je predstavljen u sledećim tabelama:

\begin{tabular}{|r|r|c|c|}
\hline \multicolumn{2}{|c|}{} & Frekvencije & Procenat \\
\hline \multirow{2}{*}{ Pol } & dečak & 197 & 57,9 \\
\cline { 2 - 4 } & devojčica & 143 & 42,1 \\
\hline \multicolumn{2}{|c|}{ Total } & 340 & 100,0 \\
\hline
\end{tabular}

Tabela 1. Struktura učenika u odnosu na pol učenika

Iz tabele 1 možemo videti da je broj dečaka veći za 54 nego broj devojčica što iznosi $15,9 \%$ od ukupnog broja ispitanika.

\begin{tabular}{|l|r|c|c|}
\hline \multicolumn{2}{|c|}{} & Frekvencije & Procenat \\
\hline \multirow{3}{*}{ Uspeh } & Odličan & 195 & 57,4 \\
\cline { 2 - 4 } & Vrlo dobar & 131 & 38,5 \\
\cline { 2 - 4 } & Dobar & 14 & 4,1 \\
\hline \multicolumn{2}{|c|}{ Total } & 340 & 100,0 \\
\hline
\end{tabular}

Tabela 2. Struktura učenika u odnosu na ostaverni uspeh učenika

Iz date tabele može se primetiti da je najviše odličnih učenika, nešto manje od $60 \%$, zatim nešto manje vrlo dobrih učenika, dok je broj učenika sa dobrim uspehom najmanji i ne toliko značajan. Dovoljnih i nedovoljnih učenika nema.

\begin{tabular}{|c|l|c|c|}
\hline & & Frekvencije & Procenat \\
\hline \multirow{4}{*}{ Škola } & gimnazija & 20 & 5,9 \\
\cline { 2 - 4 } & medicinska & 79 & 23,2 \\
\cline { 2 - 4 } & ekonomska & 21 & 6,2 \\
\cline { 2 - 4 } & tehnička & 65 & 19,1 \\
\cline { 2 - 4 } & Ostalo & 155 & 45,6 \\
\cline { 2 - 4 } & Ukupno & 340 & 100,0 \\
\hline
\end{tabular}

Tabela 3. Struktura učenika u odnosu na školu koju pohađaju 
U tabeli 3 se mogu videti frekvencije koje se odnose na broj učenika određenih škola. Možemo primetiti da najveći broj učenika pohađa školu koja spada u grupu pod nazivom ostalo i odnosi se na škole kao što su geodetska, dizajnerska, vazduhoplovna i sl. Slede tehnička i medicinska škola koje imaju približan broj učenika, dok najmanji broj učenika pohađa gimnaziju i ekonomsku školu.

\subsection{REZULTATI I DISKUSIJA}

Prva hipoteza glasi da postoje razlike između dečaka i devojčica u pogledu etike, privatnosti, vlasništva i socijalnog stava kao ključnih pitanja kompjuterske etike. Za ispitivanje date hipoteze korišćena je tehnika poređenja aritmetičkih sredina pomoću T-testa.

\begin{tabular}{|c|c|c|c|c|c|c|c|}
\hline Zavisna varijabla & Pol & $N$ & $M$ & $S D$ & $t$ & $d f$ & $p$ \\
\hline \multirow{2}{*}{ Etika } & Dečak & 197 & 3,04 & 0,48 & \multirow{2}{*}{$-0,64$} & \multirow{2}{*}{338} & \multirow{2}{*}{0,523} \\
\hline & Devojčica & 143 & 3,07 & 0,46 & & & \\
\hline \multirow{2}{*}{ Privatnost } & Dečak & 197 & 3,32 & 0,62 & \multirow{2}{*}{$-4,05$} & \multirow[b]{2}{*}{326,95} & \multirow{2}{*}{0,000} \\
\hline & Devojčica & 143 & 3,58 & 0,54 & & & \\
\hline \multirow{2}{*}{ Vlasništvo } & Dečak & 197 & 2,58 & 0,69 & \multirow{2}{*}{$-2,14$} & \multirow{2}{*}{328,63} & \multirow{2}{*}{0,033} \\
\hline & Devojčica & 143 & 2,72 & 0,59 & & & \\
\hline Socijalni & Dečak & 197 & 3,39 & 0,72 & $-2,28$ & 333,88 & \\
\hline Stav & Devojčica & 143 & 3,55 & 0,59 & & & 0,023 \\
\hline
\end{tabular}

Tabela 4. Razlike između učenika u izraženosti ispitivanih konstrukata u odnosu na pol učenika

\begin{tabular}{|c|c|c|c|c|c|c|c|}
\hline & Škola & $N$ & $A S$ & $S D$ & $d f$ & $F$ & $p$ \\
\hline \multirow{4}{*}{ Socijalni stav } & gimnazija & 20 & 3,71 & 0,36 & & & \\
\cline { 2 - 6 } & $\begin{array}{c}\text { medicin- } \\
\text { ska }\end{array}$ & 79 & 3,45 & 0,67 & & & \\
\cline { 2 - 6 } & $\begin{array}{c}\text { ekonom- } \\
\text { ska }\end{array}$ & 21 & 3,51 & 0,79 & \multirow{2}{*}{4} & \multirow{2}{*}{2,77} & 0,027 \\
\cline { 2 - 8 } & tehnička & 65 & 3,63 & 0,59 & & & \\
\cline { 2 - 7 } & ostalo & 155 & 3,36 & 0,70 & & & \\
\hline
\end{tabular}

Tabela 5. Razlike između učenika u izraženosti ispitivanih konstrukata u odnosu na školu koju pohađaju

$\mathrm{Na}$ osnovu rezultata iz Tabele 4 može se zaključiti da postoje statistički značajne razlike između dečaka i devojčica u pogledu poštovanja privatnosti, vlasništva i socijalnog stava prema upotrebi interneta. Poštovanje privatnosti i vlasništva je izraženije kod devojaka koje takođe imaju pozitivniji socijalni stav prema internetu.

Ovim se naša hipoteza potvrđuje.

Druga hipoteza je da postoje razlike između učenika sa različitim uspehom u pogledu etike, privatnosti, vlasništva i socijalnog stave, kao ključnih pitanja kompjuterske etike. Za njeno ispitivanje korišćena je metoda analize varijanse gde se došlo do rezultata da ne postoje statistički značajne razlike u pogledu ispitivanih konstrukata u odnosu na uspeh učenika. Iako je istraživanje Fosa i saradnika pokazalo da učenici sa boljim uspehom imaju veću svest o moralnom ponašanju za kompjuterom, rezultati našeg istraživanja ne potrvđuju ove nalaze.

Treća hipoteza glasi da postoje razlike između učenika različitih škola u pogledu etike, privatnosti, vlasništva i socijalnog stava kao ključnih pitanja kompjuterske etike. Za ispitivanje ove hipoteze korišćena je metoda jednofaktorske analize varijanse kojom se utvrđuju razlike između više kategorija.

Iz Tabele 5 možemo zaključiti da postoje statistički značajne razlike između škola u pogledu socijalnog stava prema upotrebi interneta. Navedene razlike postoje između učenika gimnazije u odnosu na učenike iz grupe škola koja je označena kao ostalo, i učenika tehničke škole u odnosu na grupu ostalo. Učenici gimnazije imaju pozitivniji socijalni stav prema upotrebi interneta u odnosu na učenike škola iz grupe ostalo. Takođe, učenici tehničke škole imaju pozitivniji stav prema upotrebi interneta u odnosu na učenike iz grupe ostalo. Ovim rezultatima je data hipoteza delimično potvrđena.

\section{ZAKLJUČAK}

U poslednjih nekoliko godina mlade generacije odlikuje novi imidž delovanja povećane digitalne kompetentnosti. U radu smo pokušali da istražimo sposobnost mladih da funkcionalno koriste tehnologiju pridržavajući se etabliranih moralnih standarda. Pošlo se od glavne hipoteze da postoje razlike u pogledu poštovanja etičkih normi, poštovanja privatnosti, vlasništva i socijalnog stava kao ključnih pitanja kompjuterske etike u odnosu na pol učenika, uspeh i školu koju pohađaju. Razlike između učenika različitog pola pokazuju veće poštovanje etičkih normi kod devojaka, što ukazuje na veću socijalnu osetljivost devojaka. Rotenbergova je u svom istraživanju socijalne osetljivosti na moralne norme, došla do zaključka da ne postoje razlike između dečaka i devojčica, ali navodi da su te razlike pronađene u mnogim drugim istraživanjima (Rothenberg, 1968).

Druga hipoteza se odnosila na razlike između učenika različitog uspeha u pogledu poštovanja navedenih kompjuterskih etičkih normi. Istraživanje Fosa i saradnika pokazalo je da učenici sa boljim uspehom imaju veću svest o moralnom ponašanju, dok rezultati našeg istraživanja ne potvrđuju ove nalaze (Foss, 2013). U istraživanju Rotenbergove utvrđene su značajne razlike između učenika sa boljim uspehom u odnosu na učenike sa slabijim uspehom (Rothenberg, 1968). U našem istraživanju nema učenika sa nedovoljnim i dovoljnim uspehom, dok je sa dobrim uspehom samo $4,1 \%$ učenika, što može biti uzrok izostanka razlika.

Treća hipoteza je delimično potvrđena, jer su utvrđene razlike samo u pogledu socijalnog stava prema internetu, dok razlike prema poštovanju privatnosti, vlasništva i poštovanja etičkih normi nisu pronađene. Na osnovu ovih rezultata možemo zaključiti da svi imaju isti odnos prema ključnim pitanjima kompjuterske etike i da ne postoje razlike u odnosu na školu koju pohađaju.

Podaci dobijeni istraživanjem su kvantitativno obrađeni i ukazuju na određene razlike između dve ili više grupa ispitanika. Prilikom klasifikacije i obrade podataka moglo se uočiti da odgovori učenika kod većeg broja stavki ukazuju na nizak nivo poznavanja etičkih normi i kod većine odgovora se može videti da se učenici slažu, pomalo se slažu ili se delimično slažu sa većinom tvrdnji koje iniciraju neku vrstu zanemarivanja etičkih normi. Kako bi se došlo do relevantnijih podataka, kod ovakve 
vrste problema predlaže se kvalitativna obrada podataka koja bi dala jasniju sliku i ukazala na segment kompjuterske tehnike i poštovanja normi na koji bi posebno trebalo obratiti pažnju.

U svetlu ovih nalaza poželjno je sprovesti obrazovnu, edukativnu kampanju koja bi naglasila pravila vezana za upotrebu interneta i poštovanje kompjuterskih etičkih normi.

\section{LITERATURA}

Bruschi, B., et al. (2009). Adolescents on the net: a study on the ethical representation, Revista de Psicología International Journal of Developmental and Educational Psychology, Università degli Studi di Torino INFAD, 289-298.

Burkart, P., \& Schwarz, A. J. (2013). Post-Privacy and Ideology, In: Jansson, A. \& Christiansen, M. (eds.) Media, Surveillance and Identity: A Social Perspective. New York: Peter Lang, pp. 218-237.

Cortina, J. M. (1993). What is coefficient alpha? An examination of theory and applications. Journal of Applied Psychology, 78(1), 98-104.

Džonson, D. (2006). Kompjuterska etika. Beograd: Službeni glasnik.

Foss, E., et al. (2013). Adolescent Search Roles, Human-Computer Interaction Lab, University of Maryland.
Kohlberg, L. (1966). Moral Education in the Schools: A Developmental View. The School Review, 74(1), 1-30.

Krneta, Lj., Potkonjak, N., \& Potkonjak, M. (1965). Pedagogija. Beograd: Zavod za izdavanje udžbenika SRS.

Land, M. (2013). Toward an International Law of the Internet. Harvard International Law Journal, 54(2), 394-458.

Nikčević, I., \& Marković, E. (2013). Korišćenje savremenih informacionih tehnologija učenika u srednjoškolskim domovіта, Зборник радова ХІІ међународни скуп Синергија, Бјељина, 217 - 224.

Popović, B. (1977). Moralni razvoj i moralno vaspitanje. Beograd: Institut za pedagoška istraživanja; Beograd: Prosveta.

Rothenberg, B. B. (1968). Children's social sensitivity and the relationship to interpersonal competence, intrapersonal comfort and intellectual level. Princeton, N.J: Educational Testing Service.

Singer, P. (2004). Uvod u etiku. Novi Sad: Izdavačka knjižarnica Zorana Stojanovića.

Suzić, N. (2005). Pedagogija za XXI vijek. Banja Luka: TT-Centar. Šimleša, P. (1971). Pedagogija. Zagreb: Pedagoško-književni zbor.

Tadić, N. (2010). Psihijatrija detinjstva i mladosti. Beograd: Naučna knjiga.

Trnavac, N., \& Đorđević, J. (2002). Pedagogija. Beograd: Naučna knjiga. 